\title{
Hydromechanical behaviour of a silty sand from a steep slope triggered by artificial rainfall: from unsaturated to saturated conditions
}

\author{
Francesca Casini, Victor Serri, and Sarah M. Springman
}

\begin{abstract}
This paper presents an experimental investigation aimed at studying the hydromechanical behaviour of a silty sand from a steep slope in Ruedlingen in the northeast of Switzerland, where a landslide-triggering experiment was carried out. The hydromechanical behaviour of the statically compacted Ruedlingen silty sand has been studied under saturated and unsaturated conditions, beginning with different initial void ratios and water contents. The specimens were prepared in the laboratory using static compaction, to reproduce the mean dry density and mean water content expected in natural unsaturated in situ conditions, thus promoting specimen homogeneity and test repeatability. The choice of compaction parameters was supported by a detailed physical and microstructural investigation to produce laboratory specimens with a similar microstructure to that of the natural soil. The aim of the work was to characterize the mechanical behaviour of the soil at different gravimetric water contents in a triaxial stress path apparatus and to link the mechanical behaviour with the soil-water retention curve obtained under suction-controlled conditions with different void ratios. Soil specimens with three different gravimetric water contents were exposed to conventional isotropically consolidated drained and undrained stress paths for the water phase and to stress paths simulating in situ anisotropic compression followed by a decrease of mean effective stress at constant axial load. The radial deformation of the unsaturated specimens was measured with a laser device installed in a triaxial stress path cell. Results have been interpreted using a Bishop stress approach, evaluating the suction through the water retention curve. A simple equation has been proposed to model the compressibility behaviour of the soil tested, which depends on the parameter $\chi$ and the stress ratio $\eta$. Possible unstable response along the stress path analysed has been investigated by means of second-order work and the validity of a unified framework has also been verified under unsaturated conditions.
\end{abstract}

Key words: unsaturated soil, shallow landslide, water retention curve, instability, triaxial stress path tests.

Résumé : Cet article présente une étude expérimentale visant à étudier le comportement hydromécanique d'un sable silteux provenant d'une pente raide à Ruedlingen dans le nord-est de la Suisse, où un essai de glissement de terrain provoqué a été réalisé. Le comportement hydromécanique du sable silteux de Ruedlingen, compacté statiquement, a été étudié en conditions saturées et non saturées, en débutant avec différents indices des vides et teneurs en eau initiaux. Les échantillons ont été préparés au laboratoire par compaction statique afin de reproduire la densité sèche moyenne et la teneur en eau moyenne réalistes dans des conditions naturelles in situ, et de favoriser l'homogénéité des échantillons et la reproductibilité des essais. Le choix des paramètres de compaction s'est fait selon une étude détaillée des paramètres physiques et microstructuraux, dans le but de reproduire des échantillons de laboratoire ayant une microstructure similaire à celle d'un sol naturel. L'objectif de cette étude était de caractériser le comportement mécanique du sol à différentes teneurs en eau gravimétriques avec un appareil triaxial de cheminement des contraintes et de relier le comportement mécanique avec la courbe de rétention d'eau du sol obtenue dans des conditions de succion contrôlée avec différents indices des vides. Des échantillons de sol ayant trois teneurs en eau gravimétriques différentes ont été exposés à des cheminements de contraintes conventionnels isotropes, consolidés, drainés et non drainés, pour simuler la compression anisotrope in situ suivie d'une diminution de la contrainte effective moyenne a charge axiale constante. La déformation radiale des échantillons non saturés a été mesurée à l'aide d'un appareil au laser installé dans une cellule triaxiale. Les résultats ont été interprétés avec l'approche des contraintes Bishop, qui évalue la succion par la courbe de rétention d'eau. Une équation simple a été proposée pour modéliser le comportement en compression du sol testé. Cette équation dépend du paramètre $\chi$ et du ratio des contraintes $\eta$. Les réponses instables possibles le long du cheminement des contraintes analysé ont été étudiées avec le travail de deuxième ordre, et la validité d'une méthode unifiée a aussi été vérifiée en conditions non saturées. [Traduit par la Rédaction]

Mots-clés : sol non saturé, glissement de terrain peu profond, courbe de rétention d'eau, instabilité, essais triaxiaux de cheminement des contraintes.

\section{Introduction}

Large areas of Switzerland are exposed to the risk of rapid mass movements on steep slopes through landslides, avalanches, and debris flows, which represent significant natural hazards (Springman et al. 2012). A multi-disciplinary project called TRAMM has been implemented to investigate the triggering mechanisms of such rapid mass movements. The primary focus of this research project is to enhance the understanding of triggering and initiation mechanisms, including the transition from slow to fast mass movement processes, and flow characteristics of catastrophic

Received 13 March 2012. Accepted 22 October 2012.

F. Casini. Departamento de Ingeniería del Terreno, Cartográfica y Geofísica, C.JORDI GIRONA 1-3, Universitat Politècnica de Catalunya, 08034 Barcelona, Spain; formerly Institute for Geotechnical Engineering, Wolfgang Pauli Strasse 14, ETHZ, 8093 Zurich, Switzerland.

V. Serri. Departamento de Ingeniería del Terreno, Cartográfica y Geofísica, C.JORDI GIRONA 1-3, Universitat Politècnica de Catalunya, 08034 Barcelona, Spain.

S.M. Springman. Institute for Geotechnical Engineering, Wolfgang Pauli Strasse 14, ETHZ, 8093 Zurich, Switzerland.

Corresponding author: Francesca Casini (e-mail: francesca.casini@upc.edu). 
mass movements (www.cces.ethz.ch/projects/hazri/tramm). The influence of rainfall events on slope stability was studied by instrumenting a natural slope in Ruedlingen, Switzerland, and subjecting it to a series of artificial rainfall events. The project was designed to replicate the effects of a heavy rainfall event in May 2002, in which $100 \mathrm{~mm}$ rain fell in $40 \mathrm{~min}$ (Fischer et al. 2003), causing 42 surficial landslides in the locality.

The top soil is a loose silty sand with significant macroporosity around grain accumulations or peds, having an increasing percentage of clay with depth. To better understand the hydromechanical conditions leading to initiation of failure mechanisms, an extensive experimental investigation was planned that encompasses both saturated and unsaturated conditions. The results of the unsaturated and saturated statically compacted specimens tested under triaxial stress conditions will be discussed herein.

The compressibility behaviour has been analysed using a Bishop (1959) stress approach, and a simple equation is proposed to model the results based on the modified Cam clay model (MCCM), which depends on the stress ratio $\eta$ (Schofield and Wroth 1968), the effective stress parameter $\chi$ (Bishop 1959), and a parameter $a$ that controls the rate of change of the preconsolidation pressure induced by change in parameter $\chi$ (Jommi 2000; Tamagnini 2004; Casini et al. 2007).

The occurrence of instability during the shearing phase has been explored by means of Hill's (1958) sufficient condition of stability, which is based on the sign of the second-order work. This criterion has been applied recently to the Petacciato and Trevoux landslides by Lignon et al. (2009). The authors concluded that the second-order work criterion enables successful prediction of the primary unstable zones on these slopes that may result from a long rainy period.

The sign of the second-order work increment, calculated from the experimental results, should became negative representing a possible unstable behaviour according to Hill's condition. This should be a valuable tool for identifying impending collapse, as shown by Daouadji et al. (2010) and Chang et al. (2011) on saturated clean sands, by Monkul et al. (2011) on a saturated silty sand, and by Casini et al. (2010) on the saturated natural samples of Ruedlingen silty sand. These authors have focused mainly on the behaviour of the soil under saturated conditions, whereas the same criteria is applied to both saturated and unsaturated specimens in this paper by using a Bishop stress approach to analyse the data. The results are interpreted within a unified framework proposed by Chu et al. (2003), which has been extended to unsaturated conditions with the aim of providing a useful model for the response.

\section{Test site}

The test site is located just above the river Rhine, in the Swiss midlands of northeast Switzerland. The bedrock consists mainly of sedimentary molasse (Labhart 2005) and the landscape shows many signs of creeping surficial deposits. Several old landslides have been mapped, often initiating in damper zones. The $38^{\circ}-40^{\circ}$ slope was subjected to extreme artificial rainfall in October 2008 over a period of 4 days, with a rainfall intensity of $15 \mathrm{~mm} / \mathrm{h}$ for 2 days and an intensity of $30 \mathrm{~mm} / \mathrm{h}$ for the last 2 days. The sprinklers were distributed at an even spacing along the central line of the instrumented section of the slope ( $7 \mathrm{~m}$ wide by $35 \mathrm{~m}$ long). Some surface movements were detected during this extreme event, although failure did not occur (Akca et al. 2011). Subsequently, a range of measures were implemented, such as relocating the distribution of the sprinklers to provide more rainfall to the upper part of the slope, so that a failure mechanism was triggered in March 2009, incorporating about $150 \mathrm{~m}^{3}$ of debris (Springman et al. 2009; Casini et al. 2010; Askarinejad et al. 2012).
Table 1. Mean physical properties of the soil (after Springman et al. 2009).

\begin{tabular}{|c|c|c|c|c|}
\hline $\begin{array}{l}\text { Unit weight } \\
\text { of solids, } \\
\gamma_{\mathrm{s}}\left(\mathrm{kN} / \mathrm{m}^{3}\right)\end{array}$ & $\begin{array}{l}\text { Plasticity } \\
\text { index, } \\
I_{P}(\%)\end{array}$ & $\begin{array}{l}\text { Gravimetric } \\
\text { water content, } \\
w(\%)\end{array}$ & $\begin{array}{l}\text { Unit weight, } \\
\gamma\left(\mathrm{kN} / \mathrm{m}^{3}\right)\end{array}$ & $\begin{array}{l}\text { Void ratio, } \\
e\end{array}$ \\
\hline 25.8 & 9.9 & 19.6 & 16.7 & 0.90 \\
\hline
\end{tabular}

Fig. 1. Ruedlingen soil: in situ and laboratory grain-size distribution.

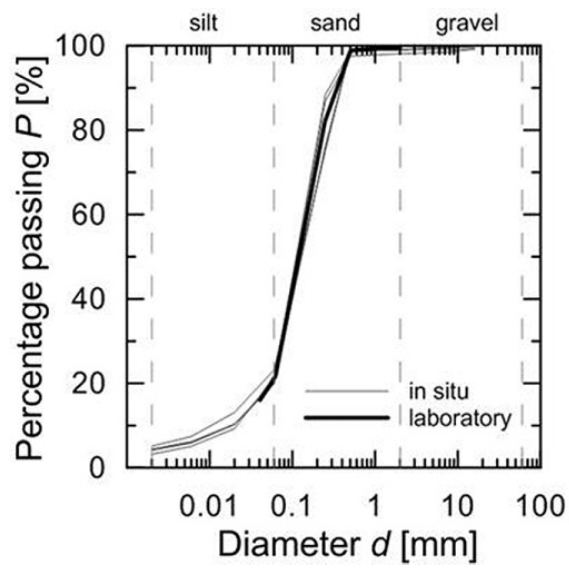

Table 2. Experimental programme.

\begin{tabular}{|c|c|c|c|c|c|}
\hline Name & $\begin{array}{l}\text { Void } \\
\text { ratio, } e_{0}\end{array}$ & $\begin{array}{l}\text { Water } \\
\text { content, } \\
w_{0}-w(\%)^{a}\end{array}$ & $\begin{array}{l}\text { Consolidation } \\
\text { obliquity, } \\
\eta=q / p^{\prime}\end{array}$ & $\begin{array}{l}\text { Total mean } \\
\text { consolidation } \\
\text { stress, } p_{c}(\mathrm{kPa})^{b}\end{array}$ & $\begin{array}{l}\text { Stress } \\
\text { path }\end{array}$ \\
\hline TX1 & 0.70 & $17-17$ & 0 & 95.2 & $\mathrm{CIU}_{\mathrm{w}} \mathrm{C}$ \\
\hline TX2 & 0.98 & $17-17$ & 0.375 & 97.7 & CADCAL \\
\hline TX3 & 0.97 & $17-17$ & 0.75 & 95.7 & CADCAL \\
\hline TX4 & 0.95 & $17-17$ & 1 & 94.5 & CADCAL \\
\hline TX5 & 0.84 & $17-25$ & 0 & 97.0 & $\mathrm{CIU}_{\mathrm{w}} \mathrm{C}$ \\
\hline TX6 & 0.94 & $17-25$ & 0.375 & 97.5 & CADCAL \\
\hline TX7 & 0.98 & $17-25$ & 0.75 & 96.3 & CADCAL \\
\hline TX8 & 0.97 & $17-25$ & 1 & 91.9 & CADCAL \\
\hline TX9 & 0.98 & $17-w_{\text {sat }}$ & 0 & 97.2 & CIUC \\
\hline TX10 & 0.91 & $17-w_{\text {sat }}$ & 0.375 & 99.5 & CADCAL \\
\hline TX11 & 0.92 & $17-w_{\text {sat }}$ & 0.75 & 100.8 & CADCAL \\
\hline TX12 & 0.94 & $17-w_{\text {sat }}$ & 1 & 98.5 & CADCAL \\
\hline
\end{tabular}

${ }^{a}$ Initial water content $w_{0}$ - water content during the test.

${ }^{b}$ Mean total stress unsaturated specimens (TX1-TX8); mean effective stress saturated specimens (TX9-TX12).

\section{Material classification}

The grain-size distribution and the natural water content together with consistency limits of the Ruedlingen soil have been determined by Casini et al. (2010, 2011), paying special attention to the spatial variability (Springman et al. 2009). The soil has been classified as medium- to low-plasticity silty sand (SM) according to the Unified Soil Classification System (USCS; ASTM 2006). The activity, $I_{A}$, of the fine fraction is higher than 1.25 in the upper part of the soil profile and decreases from 1.25 to 0.75 with increasing depth. The high activity of the soil comes from the chloritic-smectitic clay fraction (Colombo 2009). The mean physical properties of the soil are summarized in Table 1 . The specimens were reconstituted based on a representative grain-size distribution (Fig. 1), by mixing the fractions of the natural soil and omitting those fractions larger than $2 \mathrm{~mm}$. 
Fig. 2. Stress path followed in the investigation: (a) undrained for the water phase tests in saturated (CIUC) and unsaturated $\left(\mathrm{CIU} \mathrm{w}_{\mathrm{w}} \mathrm{C}\right)$ conditions; $(b)$ anisotropic consolidation - drained shear at constant axial load (CADCAL); $(c)$ WRC path in the plane suction $s=u_{\mathrm{a}}-u_{\mathrm{w}}$ versus net vertical stress $\sigma_{\mathrm{v}}-u_{\mathrm{a}}$.
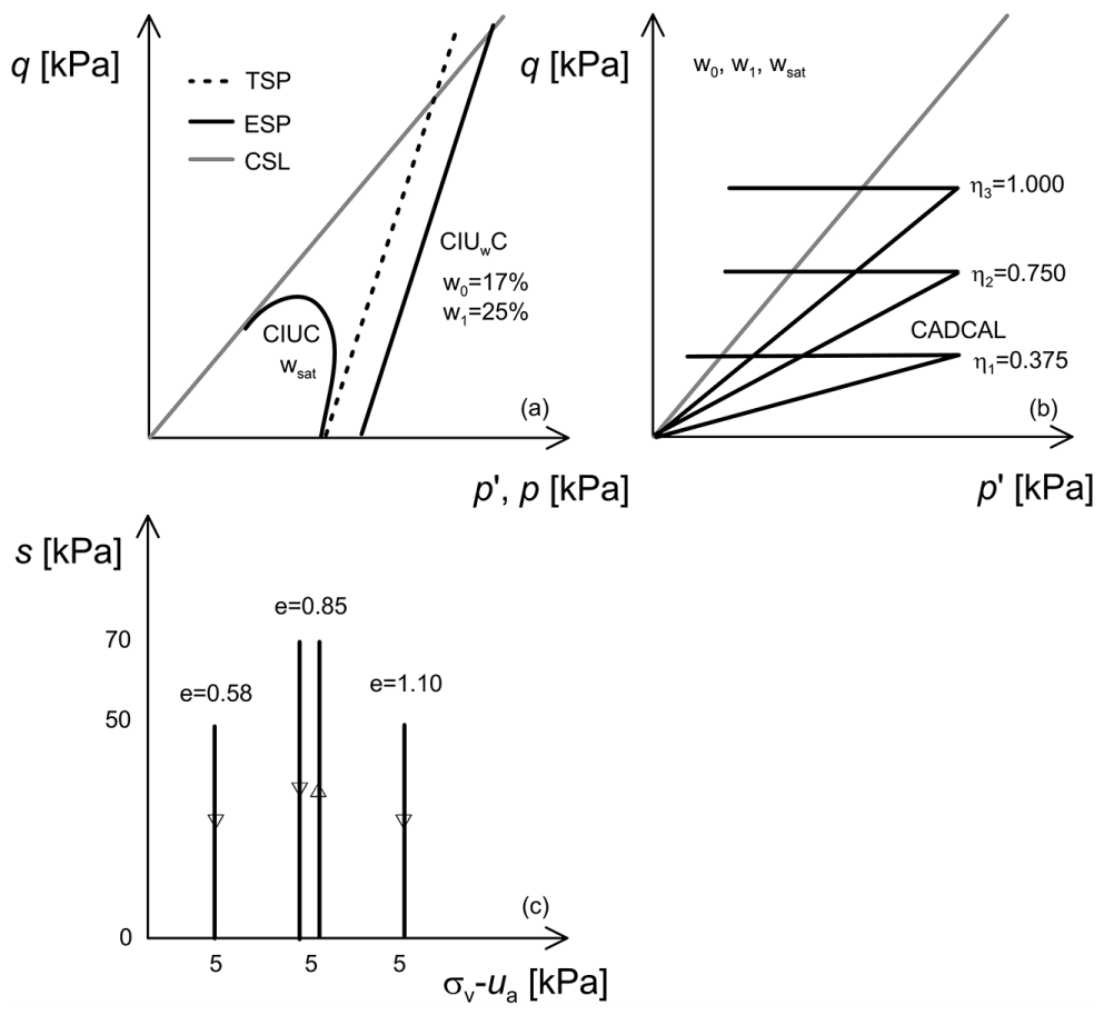

\section{Experimental programme}

The specimens were prepared using static compaction, to reproduce mean values of dry density and water content expected under natural unsaturated in situ conditions. The soils were mixed at the target water content and stored in a sealed box for $24 \mathrm{~h}$ (e.g. Casini et al 2011), then statically compacted in four layers $\left(H_{\text {layer }}=2.5 \mathrm{~cm}\right)$ in a press by controlling displacement of the piston. The choice of compaction parameters was supported by a detailed physical and microstructural investigation, in which the laboratory specimens were produced with a microstructure similar to that of the natural soil. The compacted specimens were more homogeneous than natural ones, which has contributed to repeatability of the soil behaviour. In particular, the results show a double-porosity structure for both natural and reconstituted specimens and indicate very good agreement in terms of the trend and position of the dominant void entrance diameters (see Colombo 2009). The reconstituted specimens were then prepared using static compaction with a gravimetric water content $w_{0}=0.17$ and $e_{0}=0.95$, and were tested in three modes: $(i)$ as-compacted, and by increasing the water content to (ii) $w_{1}=0.25$ and (iii) $w=$ $w_{\text {sat }}$, by infiltrating water from the bottom of the specimen.

The main objectives of the experimental programme were to characterize the behaviour under unsaturated and saturated conditions and to investigate the potential for instability of the Ruedlingen soil during shearing to failure. Conventional stress path tests were performed on specimens with three gravimetric water contents, as mentioned above, as well as on paths approaching those experienced in the field.

The soil is unsaturated under in situ conditions. The gravimetric water content range derived from monitoring was between $0.17-0.25$ to completely saturated, depending on the season. The following stress paths are investigated, representing the response of the soil in the slope:
1. CIUC: isotropic consolidation - standard undrained compression for the saturated specimens (Fig. $2 a$ ).

2. $\mathrm{CIU}_{\mathrm{w}} \mathrm{C}$ : isotropic consolidation - undrained for the water phase compression for the specimens with $w=0.17$ and 0.25 (Fig. 2a).

3. CADCAL: anisotropic consolidation - drained shear by decreasing mean effective stress at constant axial load for saturated and unsaturated specimens (Fig. $2 b$ ).

The stress path tests are summarized in Table 2.

The water retention curves (WRCs), which link the water content evolution to the suction, for the Ruedlingen soil have been obtained on specimens that were compacted statically under suction-controlled conditions to three different void ratios using a Fredlund oedometer (Askarinejad et al. 2011). A wetting path has been followed at three void ratios (Fig. $2 c$ ), while the drying path has also been followed for the specimen with a void ratio $e=0.85$. Particular attention has been paid to the evolution of the wetting path dependent on the void ratios, because it is the typical path experienced under field conditions during a rainfall event. The evolution of the WRC with void ratio plays a fundamental role in the evaluation of the stability of steep slopes due to the coupling effects of suction and degree of saturation, as highlighted by Springman et al. (2003).

\section{Experimental apparatuses}

\section{Fredlund oedometer}

The WRC of the Ruedlingen soil has been obtained under suction-controlled conditions using a Fredlund oedometer (PerezGarcia et al. 2008), for three reconstituted specimens with an initial void ratio $e_{0}=0.58,0.85,1.1$ and $w_{0}=17 \%$. The pore-air pressure, $u_{\mathrm{a}}$, was applied on top of the specimen, while the pore-water pressure, $u_{\mathrm{w}}$, was kept equal to $u_{\mathrm{w}}=\gamma_{\mathrm{w}} h_{\mathrm{w}}$, where $h_{\mathrm{w}}$ is the height of 
Fig. 3. (a) Triaxial stress path testing apparatus; (b) laser device showing three lasers mounted on a top plate; (c) section through the lasers and specimen (modified after Messerklinger and Springman 2007).
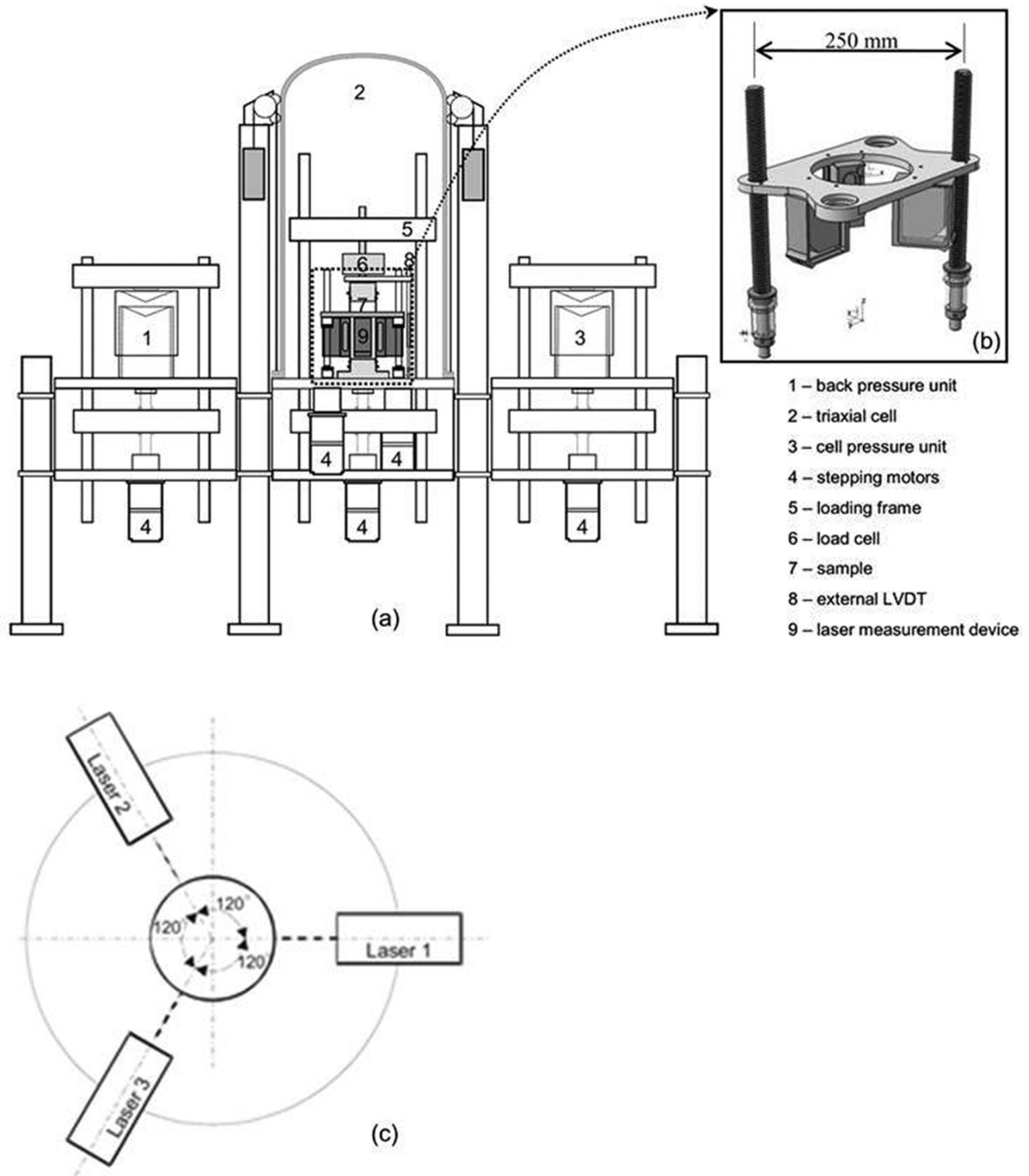

water in the burette measuring water and $\gamma_{\mathrm{w}}=9.81 \mathrm{kN} / \mathrm{m}^{3}$, the

$0.001 \mathrm{~mm}$ precision and resolution. The specimens had a diameter unit weight of water. A high air-entry value (HAEV) porous stone was placed at the bottom of the specimen to allow the flow of water in the drainage system while preventing the flow of air up to the air-entry value (100 kPa) of the porous stone. The vertical load was applied on the top of the specimen via a pressure compensator, the vertical displacement was measured using a linear variable differential transformer (LVDT) with measurement to

$D=63 \mathrm{~mm}$ and a height $H=20 \mathrm{~mm}$.

Triaxial stress path apparatus with mobile laser transducer frame

The tests were performed with a triaxial stress path testing apparatus designed and constructed at the Institute for Geotechnical Engineering (IGT: Swiss Federal Institute of Technology) in 
Fig. 4. Water retention properties of Ruedlingen soil with degree of saturation $S_{\mathrm{r}}$ versus suction (modified after Casini 2012): (a) experimental data at different void ratios along a wetting-drying paths; $(b)$ modelling of the wetting path.

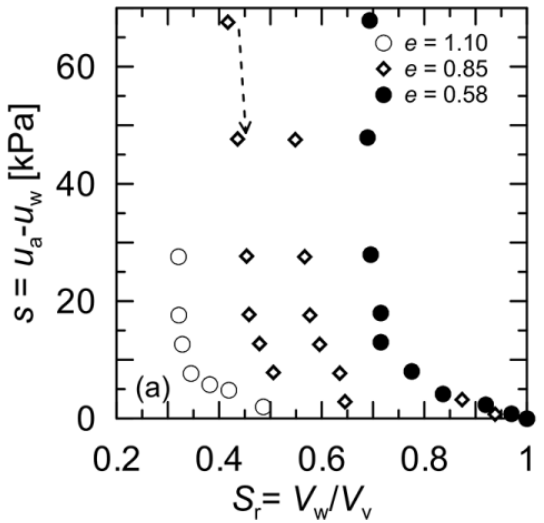

Zurich. The apparatus is a fully automated device (Fig. 3), set up to carry out tests under either controlled strain or stress rates (Arenson and Springman 2005). The specimens had a diameter $D=50 \mathrm{~mm}$ and a height $H=100 \mathrm{~mm}$.

Radial deformations were obtained by scanning over the height of the specimen with laser transducers (Messerklinger and Springman 2007) mounted in the triaxial cell on a frame and lead screws. The radial deformations of the specimen were evaluated in terms of translations, tilting or bending using three laser transducers spaced at $120^{\circ}$ in the horizontal plane (Fig. 3c).

\section{Data evaluation methods}

The data obtained by the three lasers were processed to obtain the radial deformation of the test specimen. Adopting the method proposed by Messerklinger and Springman (2007), in this work we introduce a coordinate plan for each scan, and obtain the circle that passes through the three points at each height. The cross sections are assumed to remain mainly circular.

The lasers are situated at known coordinates in the $\mathrm{x}-\mathrm{y}$ plane, subtending $120^{\circ}$ around the central specimen (Fig. 2b). Three points (one for each laser) are used to determine a circular section of the specimen over the height. The volume of the specimen was estimated by calculating the accumulated volumes of thin truncated cones (each cone is $0.15 \mathrm{~mm}$ high) with the two mean radiuses.

The velocity of the scanning device in the axial direction (along the test specimen) is $1 \mathrm{~mm} / \mathrm{sec}$. As the scanning time is less than 2 min over the $100 \mathrm{~mm}$ height, and the maximal scanning rate is $5 \mathrm{mHz}$, the change of stress during a scan cycle is considered to be negligible. This aspect should be reviewed critically if the apparatus is used for other test and (or) load conditions.

A low-pass filter has been applied to the processed data to reduce the scattering of the laser measurement. The maximum frequency used in the filter is $48 \mathrm{kHz}$; one-quarter of this frequency is used to remove the noise of the laser.

\section{Experimental results}

\section{Modelling water retention properties}

The evolution of the degree of saturation $S_{\mathrm{r}}=V_{\mathrm{w}} / V_{\mathrm{v}}\left(V_{\mathrm{w}}\right.$, volume of voids filled with water; $V_{\mathrm{v}}$, volume of voids) versus suction $s=u_{\mathrm{a}}-u_{\mathrm{w}}$ is reported in Fig. 4 . The three specimens have been compacted with the same initial gravimetric water content to the three void ratios of $0.58,0.85$, and 1.10 . The wetting path has been followed for the three specimens, and a drying path has been applied subsequently to the specimen with $e=0.85$ (Fig. 2c). The experimental results confirm the dependency of the WRC on void ratio and hysteresis as the water retained by the soil increases for the same suction as the void ratio decreases. The degree of saturation for a suction $s=10 \mathrm{kPa}$ ranges between $0.35(e=1.1)$ and

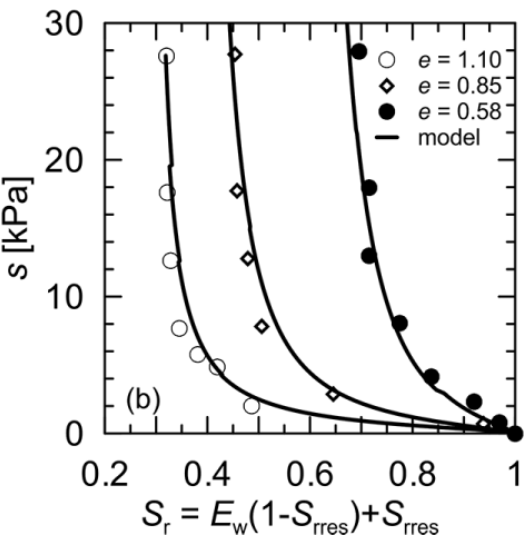

Table 3. Water retention model parameters (after Casini 2012).

\begin{tabular}{lllll}
\hline$n_{0}$ & $P_{0}(\mathrm{kPa})$ & $b$ & $l_{0}$ & $c$ \\
\hline 0.524 & 0.7 & 9 & 0.5 & -2.5 \\
\hline
\end{tabular}

$0.75(e=0.60)$, which is important in the context of triggering during a rainfall event by increasing water content.

The wetting water storage mechanism has been described using a modified van Genuchten (1980) model (after Casini 2012) in terms of dimensionless water ratio $E_{\mathrm{w}}=E_{\mathrm{w}}(s, n)$ as follows:

$$
\begin{aligned}
& E_{\mathrm{w}}=\frac{e_{\mathrm{w}}-e_{\mathrm{wres}}}{e-e_{\mathrm{wres}}}=\left\{1+[s / P(n)]^{1 /[1-l(n)]\}-l(n) ;}\right. \\
& P(n)=P_{0} \exp ^{b\left(n_{0}-n\right)} ; \quad l(n)=l_{0} \exp ^{c\left(n_{0}-n\right)}
\end{aligned}
$$

where $e_{\mathrm{w}}=V_{\mathrm{w}} / V_{\mathrm{s}}, V_{\mathrm{s}}$ is the volume of solids, $e_{\mathrm{wres}}$ is the residual water ratio, $P, P_{o}, l_{o}$, and $l$ are soil parameters that depend on porosity $n$ via parameters $b$ and $c$ (Casini et al. 2012). The hysteresis has been neglected because the specimens are mainly following a wetting path. The parameters obtained by interpreting the WRC are reported in Table 3 . A comparison between the prediction and the laboratory results for the WRC is shown in Fig. $4 b$ in terms of $S_{\mathrm{r}}$ versus $s$. The model fits the experimental results well over the variation of void ratio and in the range of suction investigated.

\section{Triaxial tests}

The experimental results are reported in terms of

$$
\begin{array}{r}
p=\frac{\sigma_{\mathrm{a}}+2 \sigma_{\mathrm{r}}}{3} ; \quad p^{\prime}=p-u_{\mathrm{a}}+\chi\left(u_{\mathrm{a}}-u_{\mathrm{w}}\right) ; \quad q=\sigma_{\mathrm{a}}-\sigma_{\mathrm{r}} \\
\varepsilon_{\mathrm{v}}=\varepsilon_{\mathrm{a}}+2 \varepsilon_{\mathrm{r}} ; \quad \Delta u=u_{\mathrm{w}}-u_{\mathrm{w} 0} ; \quad \varepsilon_{\mathrm{q}}=\frac{2}{3}\left(\varepsilon_{\mathrm{a}}-\varepsilon_{\mathrm{r}}\right) \\
=\varepsilon_{\mathrm{a}}-\varepsilon_{\mathrm{v}} / 3
\end{array}
$$

where $\sigma_{\mathrm{a}}$ is the axial total stress, $\sigma_{\mathrm{r}}$ is the radial total stress applied in the triaxial cell under axisymmetric conditions, $p$ is the mean total stress, $p^{\prime}$ is the mean effective stress, $q$ is the deviatoric stress, and $\chi$ is a weighting parameter taking into account $S_{r}$. The axial strain $\varepsilon_{\mathrm{a}}=-\Delta H / H_{0}$, where $\Delta H$ was measured over the entire specimen length, $H_{0}$ is the specimen height at the beginning of each phase, and $\varepsilon_{\mathrm{r}}=-\Delta R / R_{0}$ is the radial strain. The volumetric strain, $\varepsilon_{\mathrm{v}}=-\Delta V / V_{0}$, was deduced from water exchange by volume for the saturated specimens, while it was obtained for the subsequent unsaturated tests by measuring $\varepsilon_{\mathrm{a}}$ and $\varepsilon_{\mathrm{r}}$ from laser transducers, as explained above. The deviatoric stress is defined as 
Fig. 5. Consolidation phase for different obliquities $\eta=q / p^{\prime}:(a) \eta=0 ;(b) \eta=0.375 ;(c) \eta=0.75 ;(d) \eta=1$.
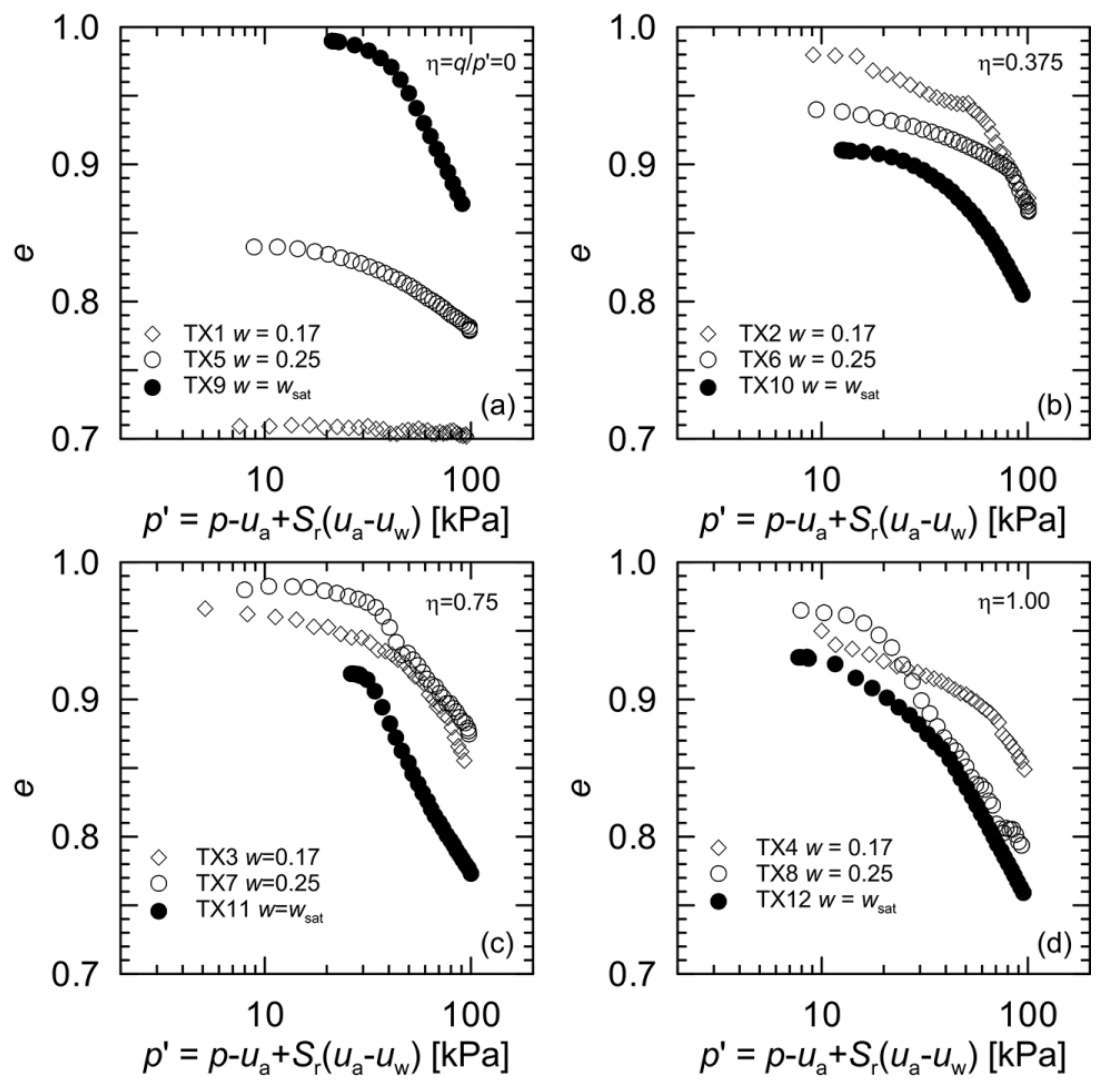

$q=\sigma_{\mathrm{a}}-\sigma_{\mathrm{r}}=\mathrm{F} / A$, where $\mathrm{F}$ is the axial force, $A$ is the current cross sectional area of the specimen, corrected assuming that the specimen remains as a right cylinder (Head 1998) linked to the initial area $A_{0}$ through $A=A_{0}\left(1-\varepsilon_{\mathrm{v}}\right) /\left(1-\varepsilon_{\mathrm{a}}\right)$. The pore pressure $u_{\mathrm{wo}}$ is defined as the value of pore pressure $u_{\mathrm{w}}$ following consolidation and at the beginning of the shearing phase.

\section{Consolidation phase}

The consolidation phase has been performed with a mean stress rate $p=3.6 \mathrm{kPa} / \mathrm{h}$ up to a mean total stress of $p=95 \mathrm{kPa}$ for four different obliquities $\eta=q / p^{\prime}$, as reported in Fig. $2 b$ and summarized in Table 2 . The suction has been evaluated through the water retention curve by following the evolution of the degree of saturation during the test. The experimental results are reported in Figs. $5 a-5 d$ for the same $\eta$ and the different gravimetric water contents, in terms of void ratio $e=V_{\mathrm{v}} / V_{\mathrm{s}}\left(V_{\mathrm{s}}\right.$, volume of solid particles) and mean skeleton stress $p^{\prime}=p-u_{\mathrm{a}}+S_{\mathrm{r}}\left(u_{\mathrm{a}}-u_{\mathrm{w}}\right)$.

The saturated specimen under isotropic conditions (Fig. $5 a$ ) shows a lower preconsolidation mean effective stress compared to the specimens with $w=0.17$ and 0.25 . This is due to a combination of higher void ratio and water content.

Generally the preconsolidation pressure increases with decreasing water content, for the obliquity investigated. For $\eta=0.375$ and 0.75 , the unsaturated specimens follow a similar path for $p^{\prime} \geq 70$ and $50 \mathrm{kPa}$, respectively (Figs. $5 b-5 c$ ).

The compressibility curves for $\eta=1$ (Fig. $5 d$ ) show a more rigid behaviour for the driest specimen $(w=0.17)$ while the specimens with $w=0.25$ and in the saturated state behave in a similar way.

\section{Compression phase}

The specimens TX1, TX5, and TX9 were axially compressed under a controlled axial deformation rate $\dot{u}=5 \times 10^{-6} \mathrm{~mm} / \mathrm{s}$ after a consolidation phase under isotropic conditions up to $p_{\mathrm{c}}^{\prime} \cong 100$

$\mathrm{kPa}$. The results are reported in Fig. 6 in the planes $\varepsilon_{\mathrm{q}}-q, p^{\prime}-q$, $\varepsilon_{\mathrm{q}}-\varepsilon_{\mathrm{v}}$, and $e-\log \left(p^{\prime}\right)$.

The peak deviator stress, $q_{\text {peak }}$, increases with decreasing water content at the same confining stress. The saturated specimen TX9 is sheared at constant volume (undrained; Fig. $6 d$ ) and shows a slightly brittle behaviour with $q_{\text {peak }}=60 \mathrm{kPa}$ and a residual $q_{\mathrm{res}}=$ $50 \mathrm{kPa}$ (Fig. $6 a$ ). The excess pore pressure, $\Delta u$, increases with $\varepsilon_{\mathrm{q}}$, displaying typical behaviour of contractant soil (Figs. $6 b$ and $6 c$, second $y$ axis). The unsaturated specimens (TX1 and TX5) exhibit an initial decrease in volume followed by dilatant behaviour. The dilatancy increases with lower water content (Figs. $6 c$ and $6 d$ ). The behaviour observed is consistent with the position of the points representing the state of the specimens at the end of the consolidation phase (Fig. 5a); the saturated specimen TX9 is on the normal compression line (NCL) at the end of the consolidation phase (expected contractant behaviour at failure) while specimens TX1 and TX5 are on an unloading-reloading line (expected dilatant behaviour at failure), with the specimen at $w=0.17$ having the greatest overconsolidation ratio and hence potential for dilation. A value of $\eta_{\mathrm{csl}}=M=$ 1.24 denotes the gradient of the critical state line (CSL), corresponding to a critical state friction angle of $\varphi^{\prime}=31^{\circ}$, and represents a good fit to the critical state conditions (Fig. 6b).

The measured degree of saturation $S_{\mathrm{r}}=e_{\mathrm{w}} / e$, and the predicted suction (via the WRC) during the axial compression phase, are reported in Fig. $6 e$ for specimens TX1 and TX5 with the initial contraction clearly shown before dilation takes over at $\varepsilon_{\mathrm{q}}>0.1$, leading to a reduced $S_{\mathrm{r}}$. The $S_{\mathrm{r}}-s$ and $E_{\mathrm{w}}-s$ paths are also reported in Fig. $6 f$. The variation of $S_{\mathrm{r}}$ due to the change in void ratio $\left(e_{\mathrm{w}}=\right.$ constant) induces a more pronounced adjustment in suction for TX1 ( $w=0.17$ ), which is due to the different initial position on the WRC according to the model reported in Fig. 4. The point representative for $S_{\mathrm{ro}}=0.6$ (TX5) is near the lower bound corner of the WRC, so a small change in $S_{\mathrm{r}}$ provokes a significant change of 
Fig. 6. Triaxial compression (after consolidation to $p_{\mathrm{c}}^{\prime}=100 \mathrm{kPa}$ ) under controlled axial displacement rate of $5 \times 10^{-6} \mathrm{~mm} / \mathrm{s}$ : $(a) \varepsilon_{\mathrm{q}}-q$ plane; (b) $p^{\prime}-q$ plane; (c) $\varepsilon_{\mathrm{q}}-\varepsilon_{\mathrm{v}}$ (TX1, TX5) and $\varepsilon_{\mathrm{q}}-\Delta u$ (TX9); (d) $\log p^{\prime}-e$ plane; (e) $S_{\mathrm{r}}$ and $s$ evolution with $\varepsilon_{\mathrm{q}}$; (f) $S_{\mathrm{r}}-s$ and $E_{\mathrm{w}}-s$.
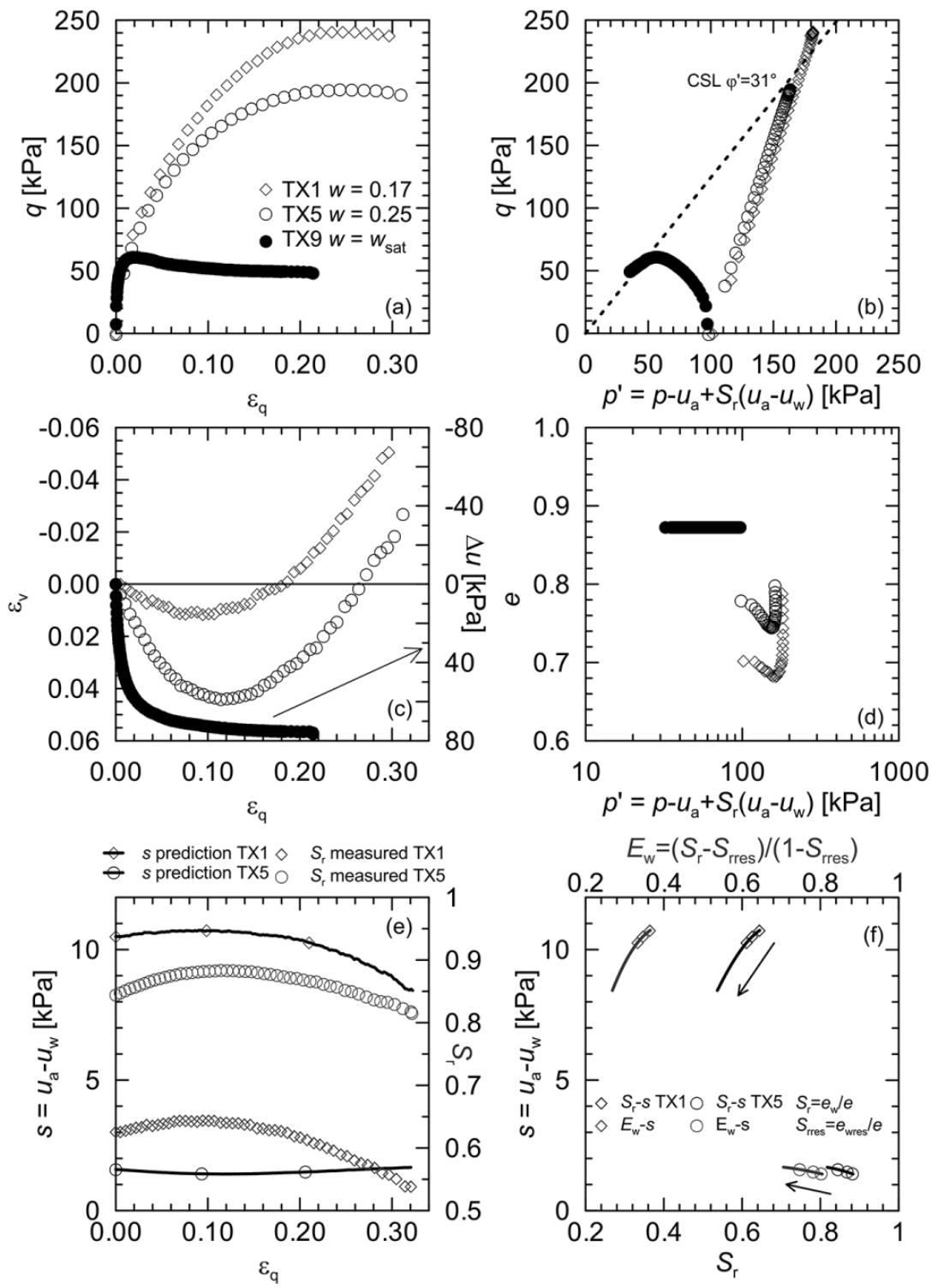

suction, while the point for $S_{\mathrm{r} 0}=0.85$ (TX1) is on the flatter part of the curve, so a variation in $S_{\mathrm{r}}$ causes a quasi-constant value of suction according to the model, as also confirmed by the $S_{\mathrm{r}}-S$ and $E_{\mathrm{w}}-s$ paths reported in Fig. $6 f$.

\section{Constant axial load phase}

Infiltration of water into the soil induces an increase of porewater pressure at mainly constant total stress, which decreases the effective stress, potentially leading to failure of the slope. To understand the triggering mechanism more deeply, it is fundamental to model the effective stress path followed in situ in the laboratory, which can be achieved in the laboratory mainly in two ways:

1. maintaining constant total stresses and increasing the porewater pressure (e.g., Casini et al. 2010);

2. maintaining constant pore-water pressure and decreasing the total stress accordingly (e.g., Springman et al. 2003 after Anderson and Sitar 1995; Zhu and Anderson 1998).

Daouadji et al. (2010), amongst others, reported that both methods gave the same results under saturated conditions. To simulate the in situ stress path, the second method has been adopted with

three different water contents ( $w=0.17,0.25$, and fully saturated). The obliquities chosen are representative of different stress states of the soil in the slope within the constraints of adopting vertical and horizontal principal stresses.

The results of the constant axial load phase for the same water content and different $\eta$ values are reported in Fig. 7 in the $p^{\prime}-q$ and $\varepsilon_{\mathrm{q}}-\varepsilon_{\mathrm{v}}$ planes. The total stress was decreased for specimens TX3 and TX4 while maintaining a constant axial load, which promotes a slight increase in volumetric strain (Figs. 7a-7b). This is likely to be the result of elastic swelling as the stress path moves inside the yield locus. After an initial contractant phase, a more pronounced increase of the swelling volumetric strain is observed for specimen TX2, which was compressed to $\eta=0.375$, denoting a dilatant mode of ultimate failure with plastic volume increase. The response of the specimen to an increase in stress obliquity $(\eta \geq 0.75)$ during the consolidation phase shows that the magnitude of strain in axial extension is suppressed in favour of greater magnitude of strain in radial extension, as the deviator strain is always positive; whereas it is negative initially for specimen TX2 with $\eta=0.375$.

The specimens with $w=0.25$ (TX6, TX7, and TX8; Figs. 7c-7d) exhibit a significant increase in volume with increasing shear 
Fig. 7. Constant axial load (CAL) phase: (a) $p^{\prime}-q$ plane $w=0.17$; (b) $\varepsilon_{\mathrm{q}}-\varepsilon_{\mathrm{v}}$ plane $w=0.17$; (c) $p^{\prime}-q$ plane $w=0.25$; (d) $\varepsilon_{\mathrm{q}}-\varepsilon_{\mathrm{v}}$ plane $w=0.25$; (e) $p^{\prime}-q$ plane $w=w_{\text {sat }} ;(f) \varepsilon_{\mathrm{q}}-\varepsilon_{\mathrm{v}}$ plane $w=w_{\text {sat }}$.
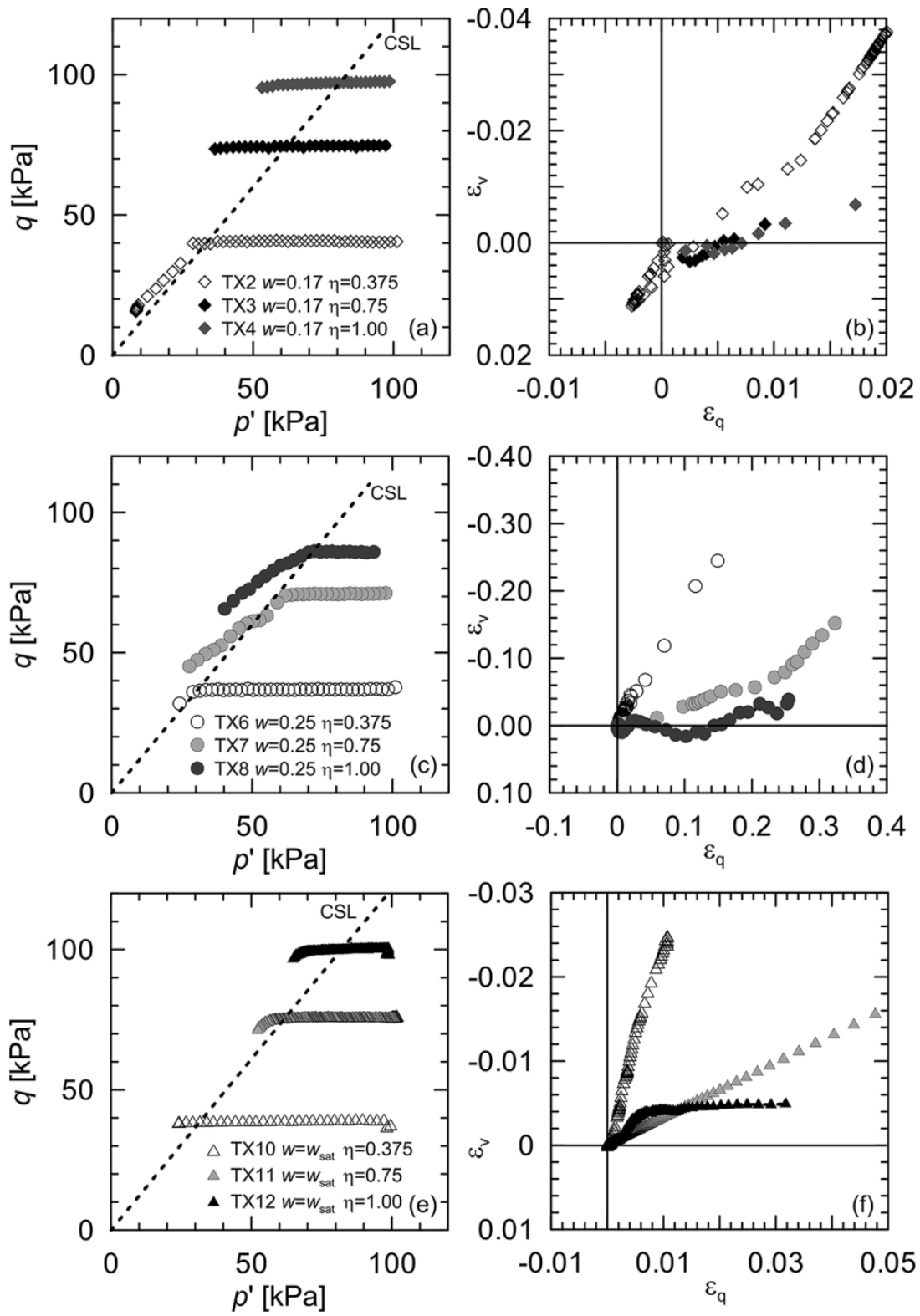

strain for two of the three obliquities investigated. Plastic volumetric strains increase as the stress path approaches and crosses the critical state line, demonstrating a dilatant mode of ultimate failure. The same behaviour is observed for saturated specimens TX11 and TX12, while specimen TX10, with $\eta=0.375$, exhibits less pronounced decreases of deviatoric stress (Figs. 7e-7f).

\section{Analysis of the results}

Model adopted in consolidation phase

The compressibility curves are modelled using the Bishop stress $\sigma_{i j}^{\prime}=\sigma_{i j}-u_{\mathrm{a}} \delta_{i j}+\chi\left(u_{\mathrm{a}}-u_{\mathrm{w}}\right) \delta_{i j}$ and suction $s=u_{\mathrm{a}}-u_{\mathrm{w}}$, where $\sigma_{i j}$ is the total stress, $\chi=\chi\left(S_{\mathrm{r}}\right)$, and $\delta_{i j}$ is the Kronecker delta (e.g., Casini et al. 2008; Nuth and Laloui 2008; Romero and Jommi 2008; D'Onza et al. 2011; Zhang and Ikariya 2011).

The mean soil skeleton (effective) stress is defined as

[3] $\quad p^{\prime}=p-u_{\mathrm{a}}+\chi\left(u_{\mathrm{a}}-u_{\mathrm{w}}\right)$

Extending the approach proposed by Casini (2012) to triaxial conditions, in analogy with saturated soils, the NCL under isotropic conditions is given as

[4] $\quad v=N_{0}(\chi)-\lambda \ln p_{\mathrm{c} 0}^{\prime}$

where $v=V_{\mathrm{v}} / V=1+e$ is the specific volume, $p^{\prime}$ is the mean soil skeleton stress defined by eq. [3], $N_{0}(\chi)$ is the specific volume at $p^{\prime}=1 \mathrm{kPa}$ for $\eta=q / p^{\prime}=0$, and $\lambda$ is the compressibility index in $v$ - $\ln p^{\prime}$ space.

The dependency of $N_{0}(\chi)$ can be obtained easily from eq. [4] and from

[5] $\quad v_{\mathrm{i}}=N_{0}(1)-\lambda \ln p_{\text {c0sat }}^{\prime}, \quad v_{\mathrm{i}}=v_{\mathrm{p}}-\kappa \ln \frac{p_{\text {c0sat }}^{\prime}}{p_{\mathrm{c} 0}^{\prime}}$

where $v_{\mathrm{i}}$ and $v_{\mathrm{p}}$ are the specific volumes in saturated and unsaturated conditions, respectively, on the NCL; $N_{0}(1)$ is the specific 
Fig. 8. Model prediction: $(a) \eta=$ constant; $(b) \chi=$ constant.

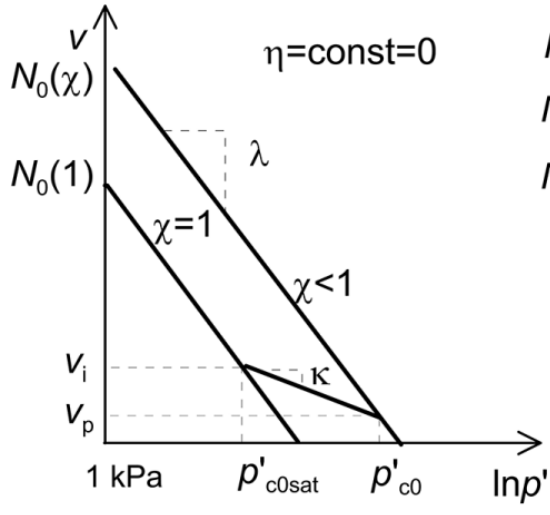

volume at a vertical stress $p^{\prime}=1 \mathrm{kPa}$ under saturated conditions; $\kappa$ is the swelling index. The relation between the saturated and unsaturated preconsolidation pressures is given by (after Jommi 2000)

$$
p_{\mathrm{c} 0}^{\prime}=p_{\mathrm{c} 0 \mathrm{sat}}^{\prime} \exp [a(1-\chi)]
$$

and by substitution of eq. [4] into eq. [5] using eq. [6]

$$
\text { [7] } \quad N_{0}(\chi)=N_{0}(1)+(\lambda-\kappa) a(1-\chi)
$$

A variation of $\chi$ corresponds to a translation of the NCL by an amount depending on the constitutive parameter $a$. The specific volume will reduce during a compression phase at constant suction, or with a water content change, and has a concomitant effect on the degree of saturation, which is taken into account by the variation of parameter $\chi$. This causes the position of the NCL to move downwards and towards the saturated NCL, as $\chi$ increases.

Following the modified Cam clay model (Roscoe and Burland 1968), an ellipse (ellipsoid in principal stress space) is assumed (isotropic model) for the yield locus centred along the $p^{\prime}$ axis. A convenient way in which to write the equation of the ellipse is

[8] $\frac{p_{c \eta}^{\prime}}{p_{c 0}^{\prime}}=\frac{M^{2}}{M^{2}+\eta^{2}}$

where $\eta=q / p^{\prime}$ is the obliquity and $M$ is the slope of CSL in the $p^{\prime}-q$ plane (Schofield and Wroth 1968; Wood 1990). The NCL (Fig. 8) for a generic $\eta$ can be obtained by extending eq. [4] to

[9] $\quad v_{\eta}=N_{\eta}(\chi)-\lambda \ln p_{c \eta}^{\prime}$

The dependency of $N_{\eta}(\chi)$ can be obtained from eq. [9] and from

[10] $\quad v_{\eta}=v_{\eta=0}-\kappa \ln \frac{p_{\mathrm{c} \eta}^{\prime}}{p_{\mathrm{c} 0}^{\prime}}$

where $N_{\eta}(\chi)$ is the specific volume at $p^{\prime}=1 \mathrm{kPa}, p_{c \eta}^{\prime}$ is the preconsolidation pressure obtained from eq. [8], and $v_{\eta}$ and $v_{\eta=0}$ are the specific volumes shown in Fig. 8. Substituting eq. [4] into eq. [10], $N_{\eta}(\chi)$ becomes

[11] $\quad N_{\eta}(\chi)=N_{0}(1)+(\lambda-\kappa)\left[a(1-\chi)+\ln \left(\frac{M^{2}}{M^{2}+\eta^{2}}\right)\right]$

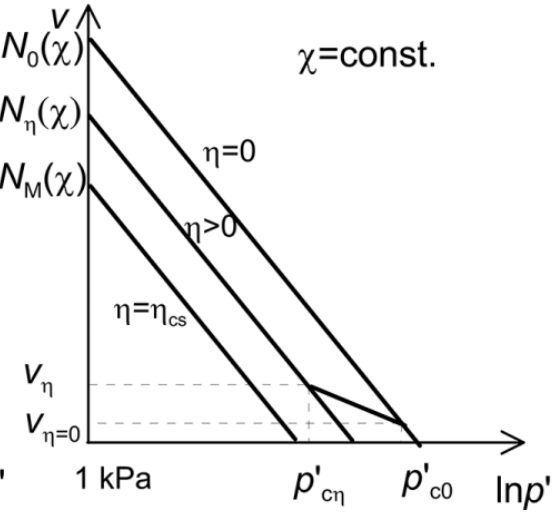

Table 4. Mechanical model parameters.

\begin{tabular}{lllll}
\hline$\lambda$ & $\kappa$ & $N_{\mathrm{o}}(1)$ & $\varphi^{\prime}\left({ }^{\circ}\right)$ & $a$ \\
\hline 0.10 & 0.02 & 2.33 & 31 & 0.17
\end{tabular}

where $N_{0}(1)$ is the specific volume under isotropic conditions and in the saturated state at $p^{\prime}=1 \mathrm{kPa}$. The critical state line may then be obtained from eq. [11] in the $v-p^{\prime}$ plane as function of the parameter $\chi$

$$
\begin{aligned}
& N_{\mathrm{M}}(\chi)=N_{0}(1)+(\lambda-\kappa)[a(1-\chi)-\ln (2)] \\
& v_{\mathrm{csl}}=N_{\mathrm{M}}(\chi)-\lambda \ln \left(p^{\prime}\right)
\end{aligned}
$$

The calibration of the parameters has been obtained by interpreting the experimental results by assuming the classic form proposed by Bishop $-\chi=S_{\mathrm{r}}$, and is reported in Table 4 . This classic form has been adopted due to its simplicity and because it gives prediction errors when suction $s$ increases to values typical of clayey soils. Casini (2012) proposed that any choice for the parameter $\chi$ can easily be incorporated in the model, such as the effective degree of saturation $\chi=\left(S_{\mathrm{r}}-S_{\text {rres }}\right) /\left(S_{\text {rsat }}-S_{\text {rres }}\right)$ (e.g., Lu et al. 2010) or $\chi=\left[\left(S_{\mathrm{r}}-S_{\text {rres }}\right) /\left(S_{\text {rsat }}-S_{\text {res }}\right)\right]^{\alpha}$ proposed by Alonso et al. (2010).

The comparison between the model prediction and the experimental results for the consolidation phase are reported in Fig. 9 in the plane $e-\log p^{\prime}$ for $\chi=S_{\mathrm{r}}$. The model reproduces the experimental behaviour quite well over the values of $\eta$ and $w$ tested. Some discrepancies appear to be more related to representing the elastic unload-reload lines for specimens TX1 (Fig. 9a), TX3, and TX7 (Fig. 9c). Despite the simplicity of the proposed model, the preconsolidation pressure is also well represented for the different values of $\eta$ and $w$ tested. In addition to the saturated parameters $\lambda, \kappa$, $N_{0}(1)$, and $\varphi^{\prime}$, the model requires the parameter $a$ and an accurate description of the water storage mechanism (WRC) to obtain the evolution of the degree of saturation with suction.

Figure 10 presents the evolution of the void ratio measured during the shearing phase in undrained conditions for the water phase and the evolution of the critical state line according to eq. [11]. The final point measured fit quite well with the predicted void ratio in saturated and in unsaturated conditions.

\section{Definition of instability}

The occurrence of instability has been explored by following the approach used by Casini et al. (2010) for natural samples under saturated conditions, with the second-order work vanishing during the constant axial load phase and the axial compression phase. According to Hill's stability condition, Lade and Pradel 
Fig. 9. Comparison between model prediction and experimental data for the consolidation phase: $(a) \eta=0 ;(b) \eta=0.375 ;(c) \eta=0.75$; (d) $\eta=1.00$.
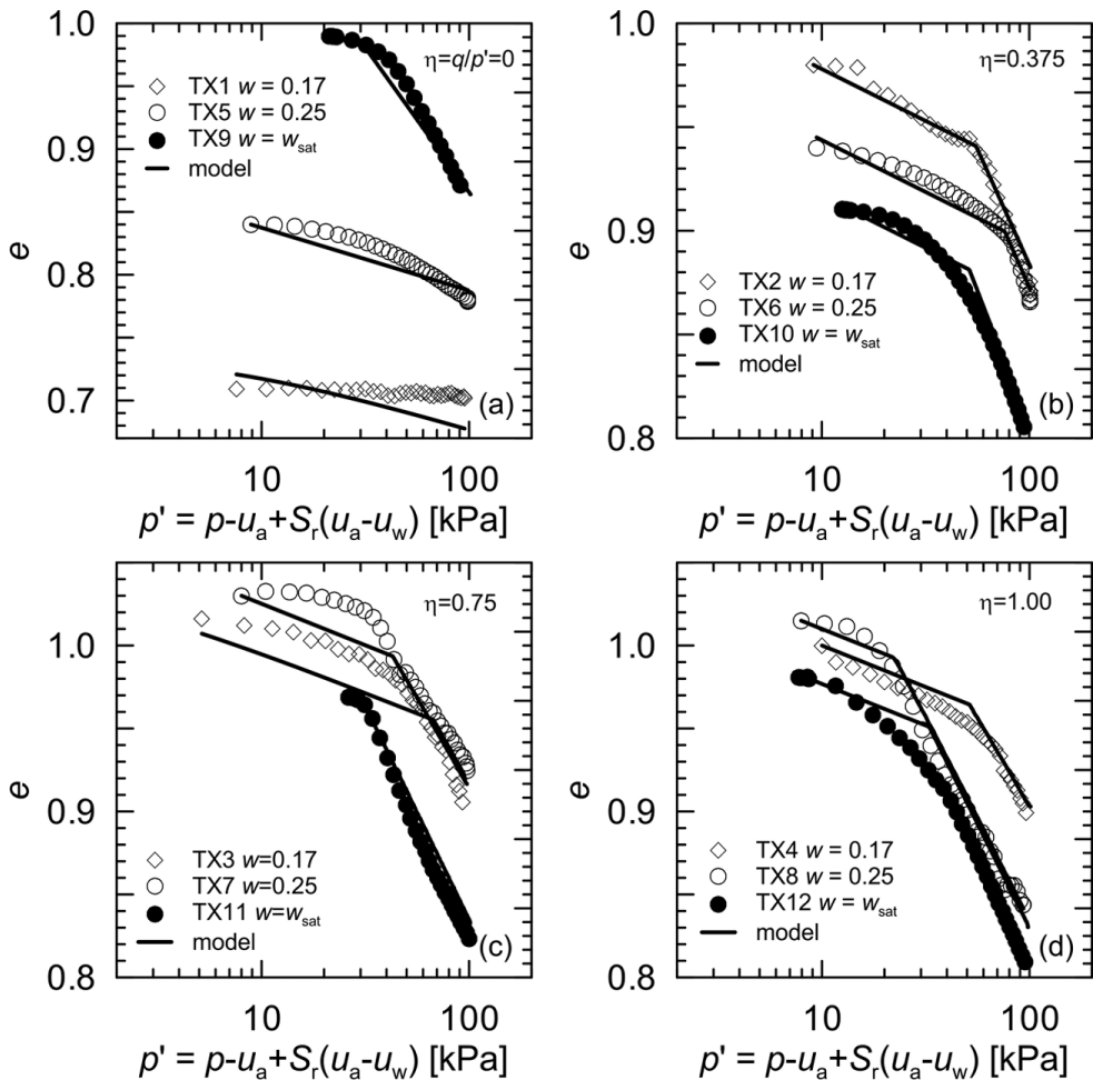

Fig. 10. Critical state soil line in the $e-\log p^{\prime}$ plane: experimental data and model prediction specimens TX1, TX5, and TX9.

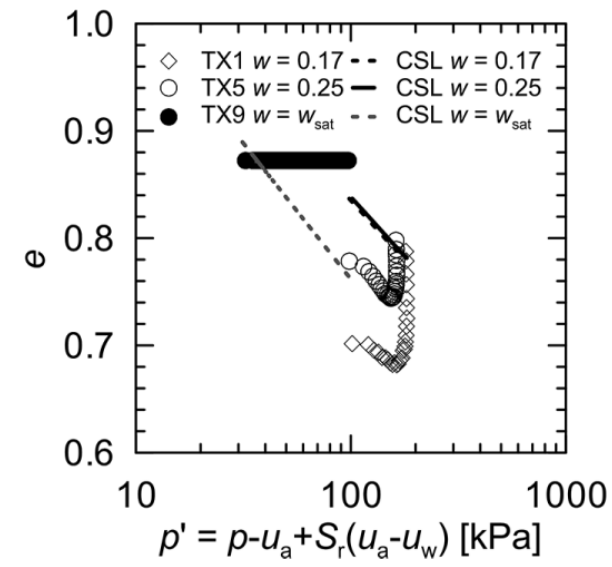

(1990) defined the second-order work increment per unit volume of material under axisymmetric conditions as

[13] $\quad \mathrm{d}^{2} W=\left(\mathrm{d} q \mathrm{~d} \varepsilon_{\mathrm{q}}\right)+\left(\mathrm{d} p^{\prime} \mathrm{d} \varepsilon_{\mathrm{v}}\right)$

The evolution of $\mathrm{d}^{2} W$ for all of the specimens is reported in Fig. 11 as a function of $\eta$. The instability ratio $\eta_{\mathrm{IL}}$ for specimen TX9 (Figs. $6 a$ and $6 b$ ), defined as the stress ratio at which the peak deviator stress occurs, is just below the critical state ratio $M=1.24$ with $\eta_{\mathrm{IL}}=1.1$. The second-order work along the undrained path for TX9 is around zero throughout the test on the saturated specimen, denoting a conditionally stable response (Fig. 11a). The evolution of $\mathrm{d}^{2} W$ for specimens TX1 and TX5 at constant water

contents of 0.17 and 0.25 , respectively, show a stable response until the peak values of stress ratio are reached, which happens for $\eta_{\mathrm{IL}}=1.33$ and 1.18 , respectively (Figs. $6 a, 6 b$, and 11a).

The data of the undrained tests are reported in Fig. 11a. A null value of $\mathrm{d}^{2} W$ is approached for values of $\eta_{\mathrm{IL}}$ ranging between 1.10 and 1.35. The second-order work is around zero for all the specimens following a constant axial load path until instability induced by decreasing mean effective stress occurs, detected by the sudden decrease of $\mathrm{d}^{2} W$ at obliquities ranging between $\eta_{\mathrm{IL}}=1.15$ and 1.5 (Figs. 11b-11d). The specimens TX3-4 and 10 (Figs. 11b-11c) show a conditionally stable response over the entire path investigated.

The framework proposed by Chu et al. (2003) (after Been and Jefferies 1985) has been adopted to study the failure mechanisms of loose and dense sand samples. The authors define a modified state parameter $e_{\mathrm{IL}}-e$ as the difference between the void ratio at instability $e_{\mathrm{IL}}$ and the void ratio at critical state $e_{\mathrm{csl}}$ for the same effective stress. They plotted $e_{\mathrm{IL}}-e_{\mathrm{csl}}$ against the stress ratio corresponding to the instability $\eta_{\mathrm{IL}}$ for both contractive and dilating soils, and defined the instability line, IL, based on yielding conditions. They concluded that the instability can occur under both undrained and drained conditions as long as the stress path leads the stress state into the zone of instability, distinguishing the occurrence of conditional stability (continuously decreasing mean effective stress in drained conditions) from that of run-away failure (under undrained conditions due to the progressive increase of pore-water pressure). The validity of the framework has been extended to unsaturated conditions, with summary data reported in Fig. 12. The void ratio at critical state $e_{\mathrm{csl}}=v_{\mathrm{csl}}-1$ is evaluated through eq. [11] with parameter $\chi=S_{\text {r. }}$.

The framework is used to examine the influences of the stress state, void ratio, and degree of saturation on the stability behaviour of granular soils in slopes subject to saturation. Conditional stability has been detected in most of the stress paths investi- 
Fig. 11. Second-order work $\mathrm{d}^{2} W$ as a function of the obliquity $\eta=q / p^{\prime}:(a)$ CADCAL $\eta=0 ;(b)$ CADCAL $\eta=0.375 ;(c)$ CADCAL $\eta=0.75$; (d) CADCAL $\eta=1.00$.
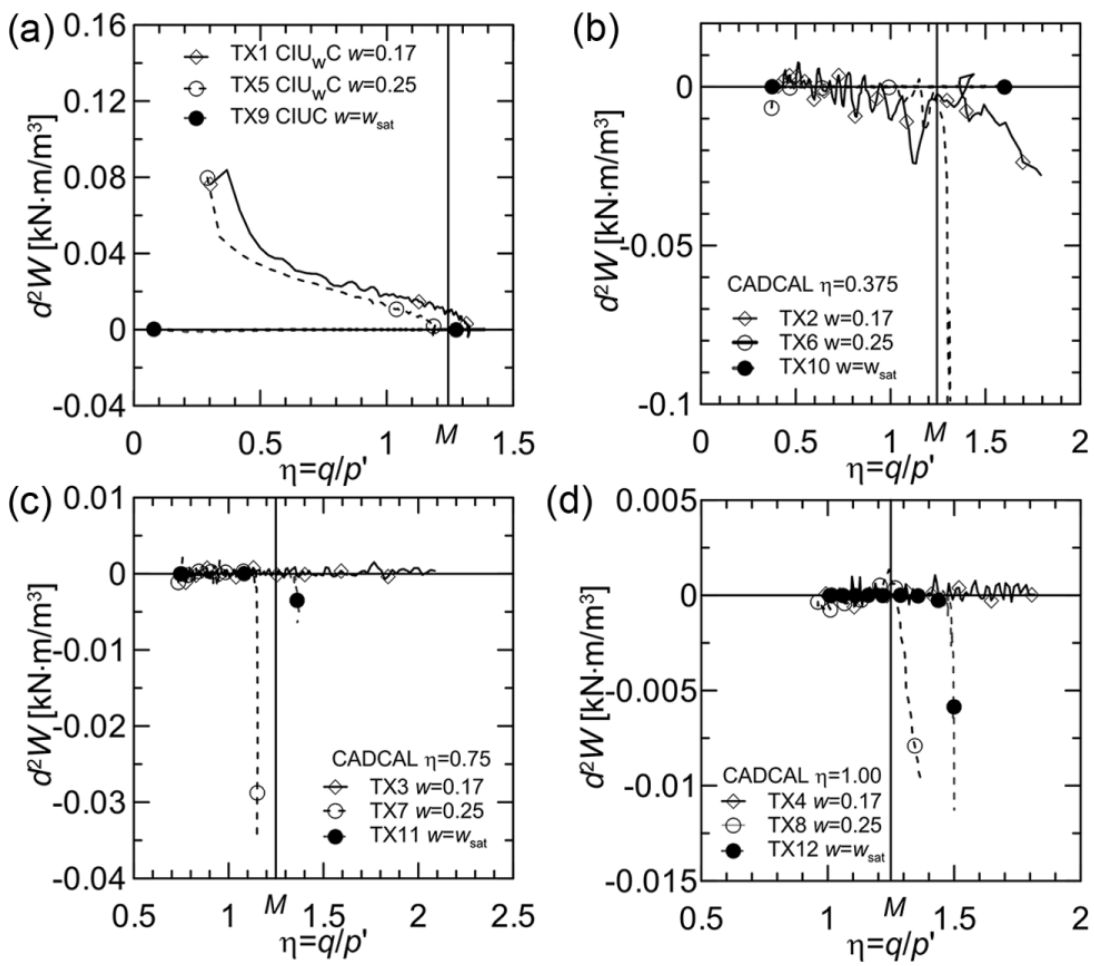

Fig. 12. Potential instability line $\eta_{\mathrm{IL}}$ as a function of the distance $e_{\mathrm{IL}}-e_{\mathrm{csl}}$ : from unsaturated to saturated condition.

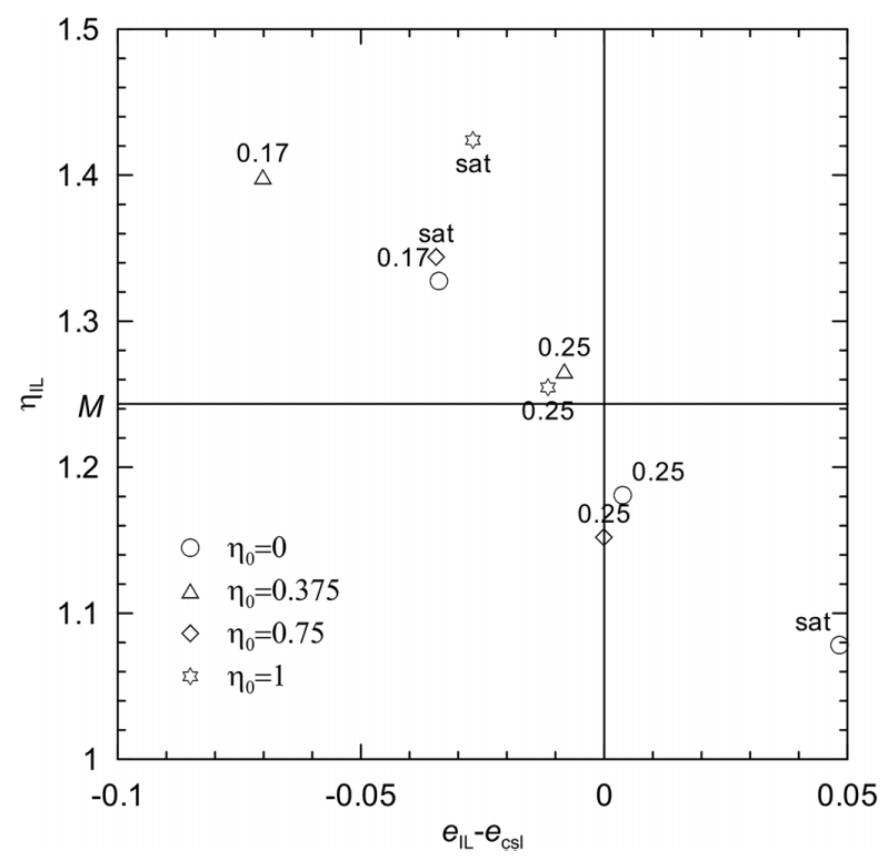

tios at the end of the consolidation phase explains the higher instability ratio exhibited by the samples with $\eta=0$ at decreasing water content. For $\eta=0.375$, only the sample with $w=0.25$ shows unstable behaviour,which may be due to the lower void ratio of the saturated samples and the bonding due to the lower degree of saturation for the driest sample $(w=0.17)$. For the other two obliquities investigated $-\eta=0.75-1-$ the samples with $w=0.25$ and the saturated ones show unstable behaviour. The samples with $w=0.25$ exhibit an instability ratio lower than the saturated ones due to higher void ratio at the end of the consolidation phase.

\section{Conclusions}

An extensive laboratory investigation has been conducted on Ruedlingen silty sand that was sampled from a steep slope where a landslide triggering experiment was carried out in March 2009. The specimens were statically compacted at the in situ mean dry density and water content, reproducing the microstructure of the natural soil fairly well.

The consolidation phase has been modelled using a Bishop stress approach and the modified Cam clay model, in which the normal compression line depends on the degree of saturation and the obliquity $\eta$. Despite the simplicity of the proposed model, it fits the results quite well for the different water contents and $\eta$ investigated. An expression for the critical state line is also provided, which depends on the degree of saturation and parameter $a$, as well as on the saturated parameters.

The instability induced by decreasing mean skeleton stress has been explored through calculation of the second-order work. Hill's criterion captures conditional stability in these specimens for the different stress paths followed rather than a properly unstable response. Temporary instability occurs due to the decreasing in effective stress for the majority of the specimens tested. The inclination of the potential instability line $\eta_{\text {IL }}$ can either be steeper or shallower than the critical state line. However, it is clear that the change in void ratio links $\eta_{\mathrm{IL}}>M$ to dilation and

gated, also in the tests under undrained conditions (TX1, TX5, TX9). This can be attributed, with respect to the natural specimens, to the specific boundary constraints of the tests and to the stabilizing effect of the fines content on the sand grain skeleton (Casini et al. 2010). The point representative of instability in the slopes under different water content and stress ratio at consolidation fits well the trend of increasing $\eta_{\mathrm{IL}}$ with decreasing $e_{\mathrm{csl}}-e_{\mathrm{IL}}$. The bonding induced by partial saturation and different void ra- 
$\eta_{\mathrm{IL}}<M$ to compression, and this is consistent also under both saturated and unsaturated conditions.

The occurrence of instability for the different obliquities investigated depends on the bonding induced by partial saturation and the void ratio at the end of the consolidation phase. During an infiltration process, the soil element in a slope can swell or shrink. The change in void ratio induced by the wetting front leads the slope to be unstable for obliquities higher or lower than the critical state line, depending on the void ratio at the end of the consolidation phase and the bonding induced by partial saturation.

\section{Acknowledgments}

This research was funded by the Competence Centre for Environment and Sustainability (CCES) within the framework of the TRAMM - Project and by FP7 within the framework of the Safeland project. The authors are grateful to Prof. Cristina Jommi for her helpful discussions, and to Ernst Bleiker and Ralf Herzog who helped with the laboratory apparatus. We are also most grateful to the Gemeinde Ruedlingen and their President Katy Leutenegger for giving permission to carry out this experiment on their land.

\section{References}

Akca, D., Gruen, A., Askarinejad, A., and Springman, S.M. 2011. Photogrammetric monitoring of an artificially generated landslide. International Conference on Geo-information for Disaster Management (Gi4DM), Antalya, Turkey, 3-8 May 2011. [CD-ROM].

Alonso, E.E., Pereira, J.M., Vaunat, J., and Olivella, S. 2010. A microstructurally based effective stress for unsaturated soils. Géotechnique 60(12): 913-925. doi:10.1680/geot.8.P.002

Anderson, S.A., and Sitar, N. 1995. Analysis of rainfall-induced debris flows. Journal of Geotechnical Engineering, 121: 544-552. doi:10.1061/(ASCE)07339410(1995)121:7(544).

Arenson, L.U., and Springman, S.M. 2005. Triaxial constant stress and constant strain rate tests on ice-rich permafrost samples. Canadian Geotechnical Journal 42: 412-430. doi:10.1139/t04-111.

Askarinejad, A., Casini, F., Kienzler, P., and Springman, S.M. 2011. Comparison between the in situ and laboratory water retention curves for a silty sand. In Unsaturated Soils - Proceedings of the 5th International Conference on Unsaturated Soils, Barcelona, Spain. Vol. 1, pp. $423-428$.

Askarinejad, A., Casini, F., Bischof, P., Beck, A., and Springman, S.M. 2012. Rainfall induced instabilities: a field experiment on a silty sand slope in northern Switzerland. Italian Geotechnical Journal, 3(12): 50-71.

ASTM. 2006. Standard practice for classification of soils for engineering purposes (Unified Soil Classification System). ASTM standard D2487. American Society for Testing and Materials, West Conshohocken, Pa.

Been, K., and Jefferies, M.G. 1985. A state parameter for sands. Géotechnique, 35(2): 99-112. doi:10.1680/geot.1985.35.2.99.

Bishop, A.W. 1959. The principle of effective stress. Tecnisk Ukeblad, 39: 859863.

Casini, F. 2012. Deformation induced by wetting: a simple model. Canadian Geotechnical Journal 49: 954-960. doi:10.1139/t2012-054.

Casini, F., Vassallo, R., Mancuso, C., and Desideri, A. 2007. Interpretation of the Behaviour of Compacted Soils Using Cam-Clay Extended to Unsaturated Conditions. In: Theoretical and Numerical Unsaturated Soil Mechanics, Springer Proceedings in Physics, 113(1): 29-36. doi:10.1007/3-540-69876-0_4.

Casini, F., Vassallo, R., Mancuso, C., and Desideri, A. 2008. Application to a compacted soil of a Cam Clay model extended to unsaturated conditions. In: Unsaturated Soils. Advances in Geo-Engineering Proceedings of the 1st European Conference, E-UNSAT 2008, Durham, United Kingdom. Edited by D.G. Toll, C.E. Augarde, D. Gallipoli, and S.J. Wheeler. pp. 609-615.

Casini, F., Jommi, C., and Springman, S.M. 2010. A laboratory investigation on an undisturbed silty sand from a slope prone to landsliding. Granular Matter 12(3): 303-316. 10.1007/s10035-010-0182-y.

Casini, F., Minder, P., and Springman, S.M. 2011. Shear strength of an unsaturated silty sand. In: Unsaturated Soils - Proceedings of the 5th International Conference on Unsaturated Soils, Barcelona, Spain. Vol. 1, pp. 211-216.

Casini, F., Vaunat, J., Romero, E., and Desideri, A. 2012. Consequences on water retention properties of double-porosity features in a compacted silt. Acta Geotechnica, 7: 139-150. doi:10.1007/s11440-012-0159-6.

Chang, C.S., Yin, Z.-Y., and Hicher, P.-Y. 2011. Micromechanical Analysis for Interparticle and Assembly Instability of Sand. Journal of Engineering Mechanics, 137(3): 155-168. doi:10.1061/(ASCE)EM.1943-7889.0000204.

Chu, J., Leroueil, S., and Leong, W.K. 2003. Unstable behaviour of sand and its implication for slope instability. Canadian Geotechnical Journal, 40, 873885. doi:10.1139/t03-039.

Colombo, L. 2009. Large shear box for analysing strength mobilisation in unsaturated conditions. Master's thesis, Politecnico di Milano.
Daouadji, A., AlGali, H., Darve, F., and Zeghloul, A. 2010. Instability in Granular Materials: Experimental Evidence of Diffuse Mode of Failure for Loose Sands. Journal of Engineering Mechanics, 136(5): 575-588. doi:10.1061/(ASCE)EM. 1943-7889.0000101.

D'Onza, F., Gallipoli, D., Wheeler, S., Casini, F., Vaunat, J., Khalili, N., Laloui, L., Mancuso, C., Mašín, D., et al. 2011. Benchmark of constitutive models for unsaturated soils. Géotechnique, 61(4): 283-302. doi:10.1680/geot.2011.61.4. 283.

Fischer, C., López, J., and Springman, S.M. 2003. Remediation of an eroded steep slope in weathered sandstone after a major rainstorm. International Conference on Landslides, Hong Kong. 878-883.

Head, K.H. 1998. Manual of soil laboratory testing, 3: Effective stress tests. Wiley, Chichester

Hill, R. 1958. A general theory of uniqueness and stability in elastoplastic solids. Journal of the Mechanics and Physics of Solids 6(3): 236-249. doi:10.1016/00225096(58)90029-2.

Jommi, C. 2000. Remarks on the constitutive modelling of unsaturated soils. In Experimental Evidence and Theoretical Approaches in Unsat. Soils, Tarantino A, Mancuso C (eds). In Proceedings of the International Workshop on Unsaturated Soils, Trento. Balkema, Rotterdam. pp. 139-153.

Labhart, T. 2005. Geologie der Schweiz. Ott Verlag. ISBN 3-7225-0007-9.

Lade, P.V., and Pradel, D. 1990. Instability and plastic flow of soils. 1: Experimental observations. Journal of Engineering Mechanics, 116(1): 2532-2550. doi: 10.1061/(ASCE)0733-9399(1990)116:11(2532).

Lignon, S., Laouafa, F., Prunier, F., Khoa, H.D.V., and Darve, F. 2009. Hydromechanical modeling of landslides with a material instability criterion. Géotechnique 59(6): 513-524. doi:10.1680/geot.7.00121.

Lu, N., Godt, J.W., and Wu, D.T. 2010. A closed form equation for effective stress in unsaturated soil. Water Resources Research 46, W05515. doi:10.1029/ 2009WR008646.

Messerklinger, S., and Springman, S.M. 2007. Local radial displacement measurements of soil specimens in a triaxial test apparatus using laser transducers. Geotechnical Testing Journal 30(6): 1-12. doi:10.1520/GTJ100735.

Monkul, M.M., Yamamuro, J.A., and Lade, P.V. 2011. Failure, instability, and the second work increment in loose silty sand. Canadian Geotechnical Journal 48: 943-955. doi:10.1139/T11-013.

Nuth, M., and Laloui, L. 2008. Effective stress concept in unsaturated soils: Clarification and validation of a unified framework. International Journal for Numerical and Analytical Methods in Geomechanics, 32(7): 771-801. doi: 10.1002/nag.645.

Perez-Garcia, N., Houston, S.I.L., Houston, W.N., and Padilla, J.M. 2008. An oedometer-type pressure plate SWCC apparatus. Geotechnical Testing Journal 31: 1-9. doi:10.1520/GTJ100964.

Romero, E., and Jommi, C. 2008. An insight into the role of hydraulic history on the volume changes and anisotropic clayey soils. Water Resources Research, 44. doi:10.1029/2007WR006558.

Roscoe, K.H., Burland,J. B. 1968. On the generalized stress strain behaviour of wet clay. In Engineering Plasticity, eds. J. Heyman, Leckie,F. A. Cambridge, England: Cambridge University Press: 535-609.

Schofield, A.N., and Wroth, C.P. 1968. Critical state soil mechanics. McGraw Hill, London, England.

Springman, S.M., Jommi, C., and Teysseire, P. 2003. Instabilities on moraine slopes induced by loss suction: a case history. Géotechnique, 53(1), 3-10. doi:10.1680/geot.2003.53.1.3.

Springman, S.M., Kienzler, P., Casini, F., and Askarinejad, A. 2009. Landslide triggering experiment in a steep forested slope in Switzerland. In: 17th International Conference on Soil Mechanics \& Geotechnical Engineering, 5-9 October, Alexandria.

Springman, S.M., Askarinejad, A., Casini, F., Friedel, S., Kienzler, P., Teysseire, P., and Thielen, A. 2012. Lessons learnt from field tests in some potentially unstable slopes in Switzerland. Acta Geotechnica Slovenica 2012/1: 5-29.

Tamagnini, R. 2004. An extended Cam-clay model for unsaturated soils with hydraulic hysteresis. Géotechnique, 54(3): 223-228. doi:10.1680/geot.2004.54. 3.223 .

van Genuchten, M.Th . 1980. A closed-form equation for predicting the hydraulic conductivity of unsaturated soils. Soil Science Society of American Journal, 44: 892-898. doi:10.2136/sssaj1980.03615995004400050002x.

Wood, D.M. 1990. Soil behaviour and critical state soil mechanics. Cambridge University Press.

Zhang, F., and Ikariya, T. 2011. A new model for unsaturated soil using skeleton stress and degree of saturation as state variables. Soils and Foundations, 51(1): 67-81. doi:10.3208/sandf.51.67.

Zhu, J.H., and Anderson, S.A. 1998. Determination of shear strength of Hawaiian residual soil subjected to rainfall-induced landslides. Géotechnique 48(1): 73-82. doi:10.1680/geot.1998.48.1.73.

\section{List of symbols}

$A$ current cross area of sample

$A_{0}$ inital cross area of sample

a parameter relating the precompression stress to degree of saturation 
$b$ parameter relating air-entry value to porosity

$c$ parameter relating the slope of WRC to porosity

$D$ sample diameter

$E_{\mathrm{w}}$ dimensionless water ratio

$e$ void ratio

$e_{0}$ initial void ratio

$e_{\mathrm{cs} l}$ void ratio at critical state line

$\mathrm{e}_{\mathrm{IL}}$ void ratio at instability line

$e_{\mathrm{w}}$ water ratio

$e_{\text {wres }}$ residual water ratio

$F$ axial force

$H$ sample height

$\Delta H$ increment of sample height

$\mathrm{H}_{\mathrm{o}}$ initial sample height

$h_{w}$ height of water in the burette measuring water

$I_{\mathrm{A}}$ activity

$I_{P}$ plasticity index

$l$ parameter relating porosity to slope of WRC

$l_{0}$ parameter relating a reference porosity to slope of WRC

$M$ slope of the critical state line in $p^{\prime}-q$ plane

$N_{0}(1)$ specific volume at $1 \mathrm{kPa}$ under saturated conditions

$N_{0}(\chi)$ specific volume at $1 \mathrm{kPa}$ under unsaturated conditions

$N_{\mathrm{M}}(\chi)$ specific volume at $1 \mathrm{kPa}$ for the critical state line

$N_{\eta}(\chi)$ specific volume at $1 \mathrm{kPa}$ depending on obliquity

$n$ porosity

$n_{0}$ initial porosity

$P$ parameter relating air-entry value to porosity

$P_{0}$ parameter relating air-entry value to a reference porosity

$p$ mean total stress

$p^{\prime}$ mean effective stress

$\mathrm{d} p^{\prime}$ increment of mean effective stress

$p_{c}$ total mean consolidation stress

$p_{c}^{\prime}$ mean effective stress under isotropic condition

$p_{\mathrm{c} 0}^{\prime}$ mean effective preconsolidation stress

$p_{\text {cosat }}^{\prime}$ mean effective preconsolidation stress in saturated conditions

$p_{c \eta}^{\prime}$ mean effective preconsolidation stress at obliquity $\eta$

$q$ deviatoric stress

$\mathrm{d} q$ increment of deviatoric stress

$q_{\text {peak }}$ peak deviatoric stress

$q_{\text {res }}$ residual deviatoric stress

$\Delta R$ increment of sample radius

$R_{0}$ initial sample radius

$S_{\mathrm{r}}$ degree of saturation

$S_{\text {ro }}$ initial degree of saturation

$S_{\text {rres }}$ residual degree of saturation

$s$ suction

$\dot{u}$ axial deformation rate
$\Delta u$ pore-water pressure increment

$u_{\text {a }}$ pore-air pressure

$u_{\mathrm{w}}$ pore-water pressure

$u_{\mathrm{wo}}$ initial pore-water pressure

$\Delta V$ increment of sample volume

$V_{\mathrm{s}}$ volume of solids

$V_{0}$ initial sample volume

$V_{\mathrm{v}}$ volume of voids

$V_{\mathrm{w}}$ volume of water

$v$ specific volume

$v_{\mathrm{cs} 1}$ specific volume along critical state line

$v_{\mathrm{i}}$ specific volume in saturated condition

$v_{\mathrm{p}}$ specific volume in unsaturated condition

$v_{\eta}$ specific volume depending on obliquity

$v_{\eta=0} \quad$ specific volume in isotropic condition

$\mathrm{d}^{2} W$ second-order work

$w$ gravimetric water content

$w_{0}$ initial gravimetric water content

$w_{1}$ gravimetric water content after infiltration

$w_{\text {sat }}$ gravimetric water content at saturation

$\alpha$ exponential parameter of the effective degree of saturation

$\gamma$ unit weight

$\gamma_{\mathrm{s}}$ unit weight of solids

$\gamma_{\mathrm{w}}$ unit weight of water

$\delta_{i j}$ Kronecker delta

$\varepsilon_{\mathrm{a}}$ axial strain

$\varepsilon_{\mathrm{r}}$ radial strain

$\varepsilon_{\mathrm{q}}$ deviatoric strain

$\mathrm{d} \varepsilon_{\mathrm{q}}$ increment of deviatoric strain

$\varepsilon_{\mathrm{v}}$ volumetric strain

$\mathrm{d} \varepsilon_{\mathrm{v}}$ increment of volumetric strain

$\eta$ obliquity

$\eta_{\mathrm{o}}$ obliquity during consolidation

$\eta_{\text {CSL }}$ obliquity at critical state line

$\eta_{\mathrm{IL}}$ obliquity at instability line

$\kappa$ swelling index

$\lambda$ slope of normal compression line

$\sigma_{\mathrm{a}}$ axial total stress

$\sigma_{i j}$ total stress

$\sigma_{i j}^{\prime}$ effective stress

$\sigma_{\mathrm{r}}$ radial total stress

$\sigma_{\mathrm{v}}$ vertical total stress

$\varphi^{\prime}$ friction angle

$\chi$ weighting parameter depending on degree of saturation 